Research, part of a Special Feature on The influence of human demography and agriculture on natural systems in the Neotropics

\title{
Metropolitanization and Forest Recovery in Southern Brazil: a Multiscale Analysis of the Florianópolis City-Region, Santa Catarina State, 1970 to 2005
}

\author{
$\underline{\text { Sandra R. Baptista }}^{1}$
}

\begin{abstract}
Within the contexts of globalization and the Atlantic Forest ecoregion, I present a multiscale analysis of anthropogenic landscape dynamics in the Florianópolis city-region, Santa Catarina, southern Brazil. Drawing on field research conducted between 2000 and 2004 and a review of the literature, I examined Brazilian demographic and agricultural census data for the period of 1970 to 1995-1996. I hypothesized that economic restructuring, new institutional arrangements, and the valuation of environmental amenities and ecosystem services have contributed to forest recovery trends and thus a forest transition in the city-region. My results indicate that along with rapid urbanization, in-migration, socioeconomic polarization, and segregation, the city-region has experienced the contraction of private agricultural land area, expansion of protected areas, recovery of forests, and conversion of coastal plain ecosystems to built environments. Future analyses of forest transition dynamics should consider the spatial configurations of socioeconomic inequality in city-regions.
\end{abstract}

Key Words: Atlantic Forest; Brazil; city-region; environmental amenities; forest recovery; forest transition; globalization; land use; landscape; Latin America; metropolitanization; migration; Santa Catarina; segregation; social inequality

\section{INTRODUCTION}

City-regions around the world are shaped by the complexities and contradictions of globalization, as well as dynamics beyond globalization (Rosenau 1997, 2003, Scott 2001a,b). Rural-urban migration, urban-urban migration, and rapid metropolitanization are among the many processes by which human actions continue to transform the Earth's surface (Turner et al. 1990). Urban economies are often linked to sprawling patterns of development and have become increasingly service, consumer, information, and amenities oriented (e.g., Ley 1980, Clark et al. 2002, Gospodini 2006). Simultaneously, humanity has been profoundly transformed by the urbanization of poverty and rapid expansion of slums (United Nations Human Settlements Programme 2003). Under these circumstances, how should human development and sustainability goals be pursued to achieve ecological integrity, human well-being, equity, and social justice (Millennium
Ecosystem Assessment 2005)? What are the possibilities for fostering human-dominated landscapes in which concentrated human populations and biodiversity conservation can coexist through ecosystem stewardship (e.g., Crane and Kinzig 2005, Wright and Muller-Landau 2006)? Focusing on the period from 1970 to 2005, I explore these issues by examining transformations in the Florianópolis city-region, a landscape in the southern coastal region of the Brazilian Atlantic Forest that is undergoing rapid metropolitanization.

Since the 1990s, the Brazilian nongovernmental organization Fundação SOS Mata Atlântica and Brazil's Instituto Nacional de Pesquisas Espaciais (National Institute for Space Research) have collaborated to monitor vegetation cover changes in the Atlantic Forest (Mata Atlântica) ecoregion using satellite remote sensing data (Fundação SOS Mata Atlântica and Instituto Nacional de Pesquisas Espaciais 1993, 2002, 2006, Fundação SOS Mata 
Atlântica et al. 1998). They have released atlases summarizing their findings. According to the most recent analysis, in 2005, eight of the Brazilian states within the Mata Atlântica contained $97,906 \mathrm{~km}^{2}$ of remnants, including: $92,402 \mathrm{~km}^{2}$ of old-growth and advanced successional forests; $4634 \mathrm{~km}^{2}$ of restinga, which includes herbaceous, scrub, and arboreal formations covering beaches, dunes, and sandy coastal plains; and $870 \mathrm{~km}^{2}$ of mangrove forest (Fundação SOS Mata Atlântica and Instituto Nacional de Pesquisas Espaciais 2006). They also reported that between 2000 and 2005, forest cover alone decreased by approximately $951 \mathrm{~km}^{2}$, with $454 \mathrm{~km}^{2}(48 \%)$ of this loss in the state of Santa Catarina. The findings suggest an overall decrease in the rate of forest loss because of reduced rates in the states of Rio de Janeiro, São Paulo, Espírito Santo, and Rio Grande do Sul, which have already experienced severe deforestation, even as the states of Santa Catarina and Goiás, which have larger proportions of remaining forest cover, suffered relatively rapid rates of forest loss. At present, the Fundação SOS Mata Atlântica and Instituto Nacional de Pesquisas Espaciais (2006) atlas for the period of 2000-2005 does not provide data on forest cover change disaggregated by municipality, nor does it list the 2000 municipal-level land-cover estimates used to calculate the net deforestation of $951 \mathrm{~km}^{2}$. Should this information become available, knowledge of the direction of forest cover change for each municipality will help to reveal the spatial pattern of net forest losses and gains in Santa Catarina and other states. In Santa Catarina, despite a reported forest loss of $454 \mathrm{~km}^{2}$, it appears that oldgrowth and advanced successional forests covered approximately $21,887 \mathrm{~km}^{2}$, corresponding to $23 \%$ of the state's total area (Fig. 1). Furthermore, although analysts at Fundação SOS Mata Atlântica and Instituto Nacional de Pesquisas Espaciais determined that 122 municipalities had $<10 \%$ forest cover, they also found that 32 municipalities had $>$ $50 \%$ forest cover (Fig. 2), and many of eastern Santa Catarina's long-settled, highly urbanized, industrialized, and most densely populated municipalities appeared to contain relatively high proportions of forest cover. Garopaba, on the coast, ranked lowest in the Florianópolis city-region, with $27 \%$ forest cover; the inland municipality of Nova Trento ranked highest, with nearly $76 \%$ forest cover.

To date, few publications have addressed forest transition theory in the Brazilian context (Perz and Skole 2003, Baptista and Rudel 2006). However, many authors have discussed forest recovery in
Brazil in relation to several of the major themes that appear in the forest transition literature, e.g., urbanization, industrialization, agricultural modernization, rural exodus, environmental protection, and the valuation of environmental amenities. For instance, Caruso (1990), Marcelino et al. (2003), Vibrans (2003), Vibrans et al. (2005) have described forest recovery in several of Santa Catarina's eastern municipalities. In the case of São Paulo, reports of forest cover gains in 85 municipalities during the 1990-1995 period and in 131 municipalities during the 1995-2000 period (Fundação SOS Mata Atlântica et al. 1998, Fundação SOS Mata Atlântica and Instituto Nacional de Pesquisas Espaciais 2002) prompted Ehlers (2007) to investigate the drivers of forest recovery.

I used an interdisciplinary and multiscale approach to explore demographic and agricultural census data for the state of Santa Catarina. My analysis was informed by field research that was performed in eastern Santa Catarina between 2000 and 2004 and a review of empirical and theoretical research. I addressed the following questions. In recent decades, how have the size and spatial distribution of Santa Catarina's human population changed? How has land use changed statewide? Over the same period of time, how has the landscape of Florianópolis and its surrounding municipalities been affected by metropolitanization and migration processes? Has forest recovery occurred in concert with metropolitanization and in-migration? If so, then when, how, where, and why? Drawing on forest transition theory (e.g., Mather 1992, 2005, Grainger 1995, Mather and Needle 1998, 2000, Rudel 1998 , Rudel et al. 2005, Kauppi et al. 2006, Perz 2007), I hypothesized that forest cover has expanded in the study region during the metropolitanization process and that this forest recovery is explained by four factors: (1) economic restructuring that shifted people toward employment in nonagricultural sectors; (2) the emergence and consolidation of new institutional arrangements that were established to achieve ecosystem protection and restoration; (3) the valuation of environmental amenities and ecosystem services; and (4) trends in real estate development, tourism development, migration, and segregation linked to these three processes. 
Fig. 1. Atlantic Forest remnants in Brazil, Santa Catarina, and the Florianópolis metropolitan region (FMR) in 2005. Adapted and translated from maps available online from the Fundação SOS Mata Atlântica (http://www.sosma.org.br).
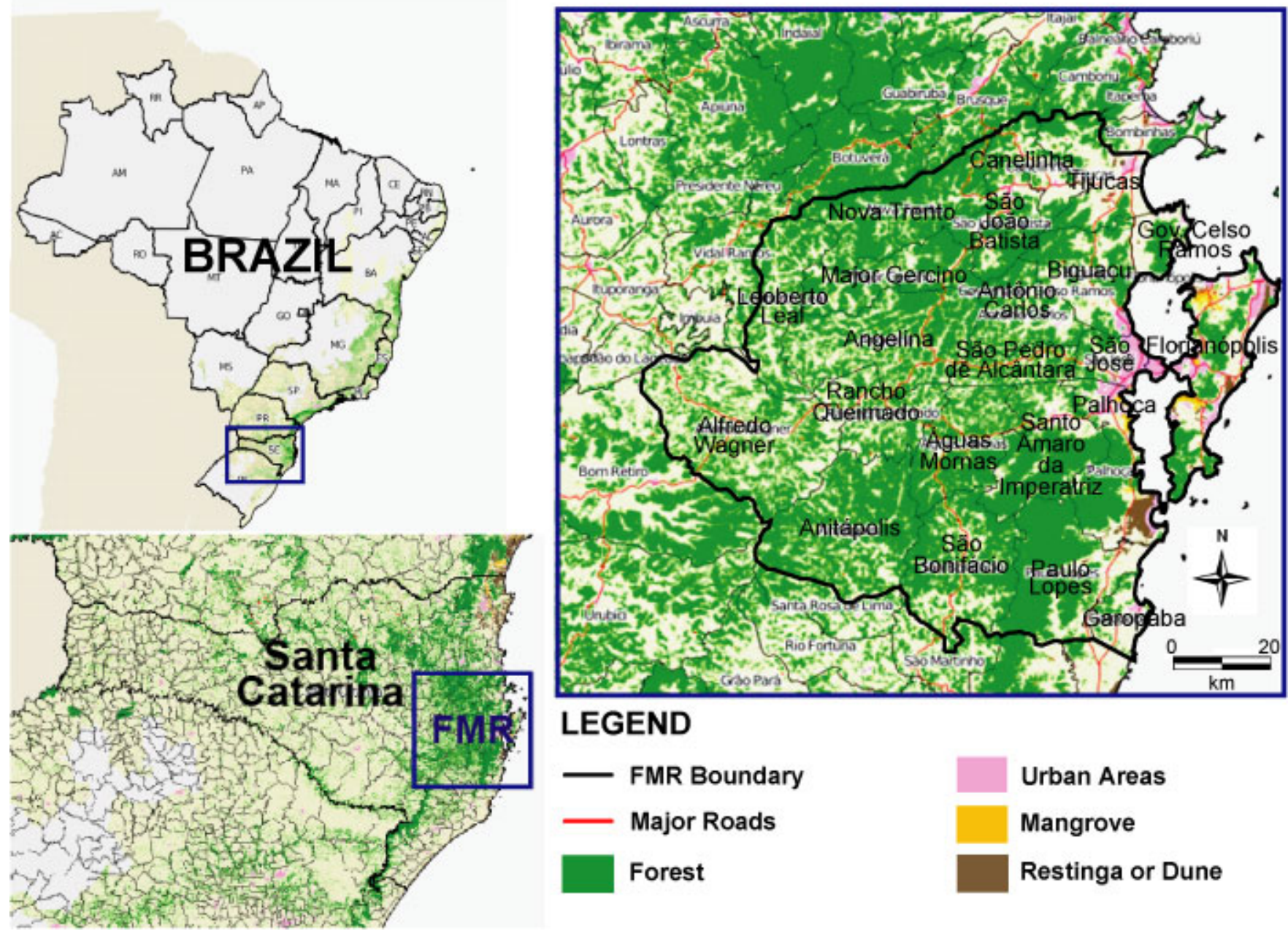

\section{LEGEND}
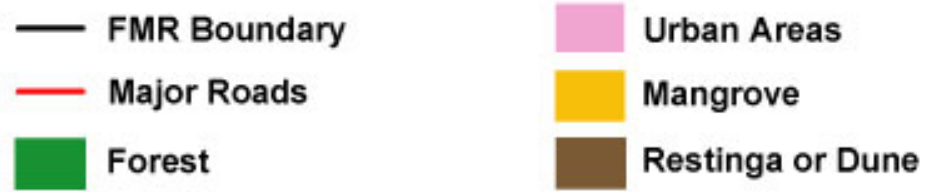

\section{METHODS}

\section{Study region}

The study region is located within the Atlantic Forest biodiversity hotspot (Cincotta et al. 2000, Myers et al. 2000, Brooks et al. 2006). Researchers and others have mobilized around the general premise that South America's original Atlantic Forest once covered $1-1.5 \times 10^{6} \mathrm{~km}^{2}$ and that as little as $6-10 \%$ of this forest remains today in fragments (e.g., Galindo-Leal and Câmara 2003, Tabarelli et al. 2005, Zurita et al. 2006). The original extent of the Brazilian Atlantic Forest (Mata Atlântica) has been cited as approximately $1.3 \times 10^{6}$ $\mathrm{km}^{2}$, and although it is often classified into two major vegetation types, i.e., coastal evergreen rain forest and interior semideciduous forest, ecological heterogeneity within this vast territory is much more complex (Morellato and Haddad 2000, Brannstrom 2002, Webb et al. 2005). Scudeller et al. (2001) have discussed the inconsistencies of phytogeographic divisions and the difficulty of defining the geographical limits of the Atlantic Forest domain and its constituent vegetation formations. Emphasizing historical, political, and institutional 
Fig. 2. Percent forest cover in the 293 municipalities of Santa Catarina, Brazil, 2005. Source: Data reported by Fundação SOS Mata Atlântica and Instituto Nacional de Pesquisas Espaciais (2006) based on the interpretation of satellite imagery.

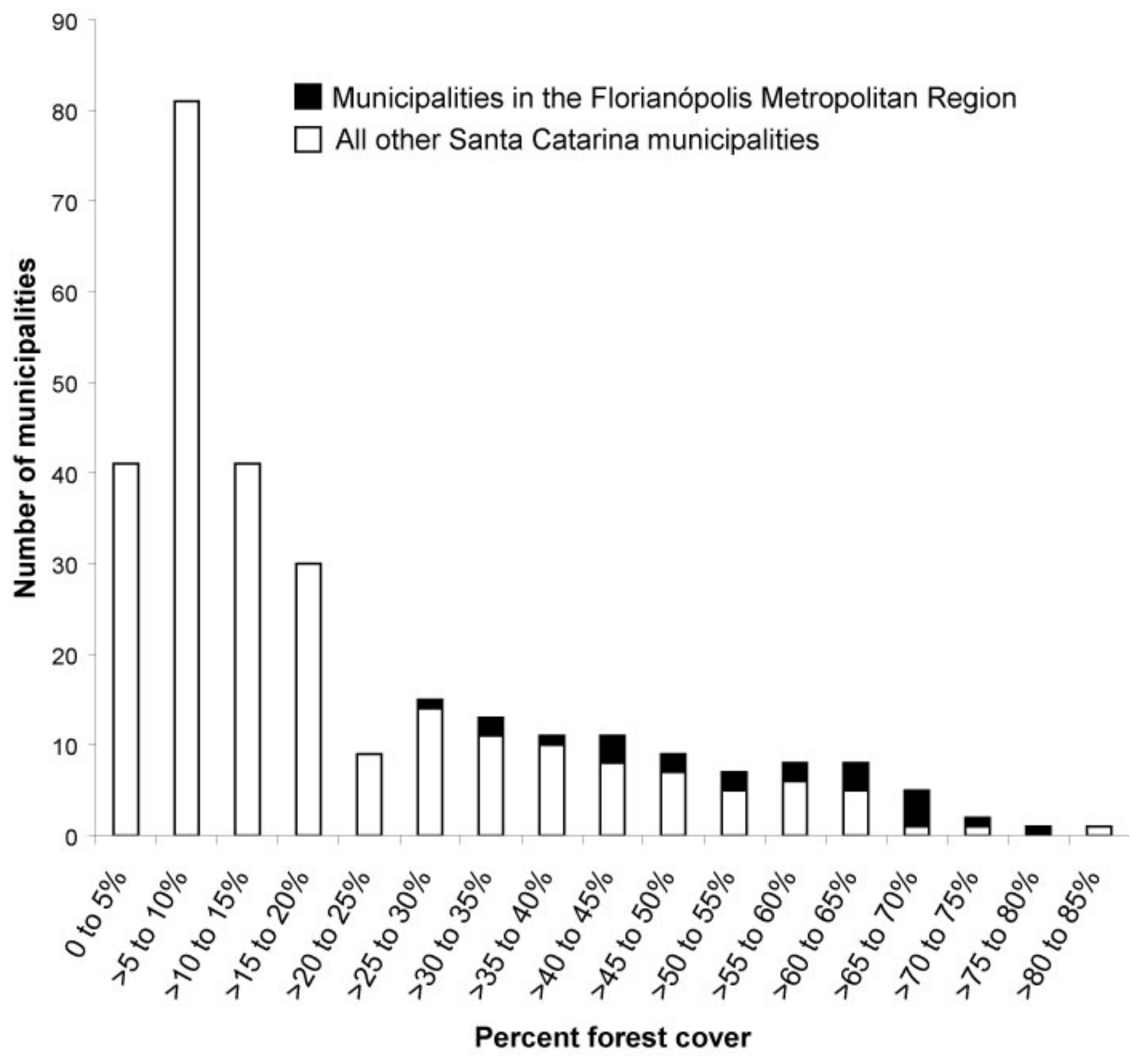


considerations, Brannstrom (2002) has called into question the invention of a monolithic Atlantic Forest. Brannstrom's (2002) focus on the early 20th century in a region of western São Paulo at a forestCerrado (tropical savanna) ecotone represents a landscape mosaic distinct from that of the region of eastern Santa Catarina described herein. Nevertheless, like Brannstrom's (2002) case, my analysis provides empirical detail and regional specificity. That is, by using a multiscale approach to examine the Florianópolis city-region during the past four decades, I describe dynamic vegetation cover in a subregion of the heterogeneous territory currently generalized as the Atlantic Forest.

Santa Catarina occupies roughly $9.5 \times 10^{4} \mathrm{~km}^{2}$, has a population of approximately $5.9 \times 10^{6}$ people, and is subdivided into 293 municipalities (Instituto Brasileiro de Geografia e Estatística 2007a). Along with Rio de Janeiro and Espírito Santo, Santa Catarina is one of three Brazilian states currently defined as being situated entirely within the Mata Atlântica domain (Instituto Brasileiro de Geografia e Estatística 2004). Nearly $1 \times 10^{6}$ people reside in the 22 municipalities of the Florianópolis metropolitan region (FMR), an area of approximately $7100 \mathrm{~km}^{2}$ (Instituto Brasileiro de Geografia e Estatística 2007a). Centered on Santa Catarina's capital city of Florianópolis (Fig. 3), the FMR $\left(27^{\circ} 14^{\prime}-28^{\circ} 01^{\prime} \quad\right.$ S, 48 $\left.20^{\circ}-49^{\circ} 20^{\prime} \quad \mathrm{W}\right)$ encompasses urban, industrial, suburban, periurban, rural, and conservation areas. Reflecting broad-scale spatial patterns of socioeconomic interdependencies, Brazil's metropolitan regions are defined by state governments to facilitate management and planning (Metrodata 2007). The terms metropolitan region and city-region are often interchangeable; however, city-region denotes a more loosely defined functional entity that lacks fixed administrative borders, whereas metropolitan region denotes an area bounded by municipal boundaries and provides a way to operationalize the city-region concept in analyses of quantitative municipality-level data.

The climate of the FMR is mesothermic, humid subtropical, with hot summers and lacking a dry season (Köppen Cfa climate classification). The mean annual temperature is $\sim 18^{\circ} \mathrm{C}$, and the mean annual precipitation is $\sim 1700 \mathrm{~mm}$ (Santa Catarina 2003). The altitude varies from coastal lowlands at $<30 \mathrm{~m}$ above sea level to inland areas at 400-1200 $\mathrm{m}$ above sea level (Santa Catarina 2000). The major ecosystems include: dense broadleaf forest that predominates in the coastal zone in association with mangrove forest and restinga; upland mixed broadleaf forest containing the conifer Araucaria angustifolia; and high-altitude grasslands (Hodge et al. 1997, Falkenberg 1999, Bonnet et al. 2007).

After millennia of occupation by indigenous peoples, colonial settlements emerged along Santa Catarina's coast during the 17th century (Cardoso and Ianni 1960, Cabral 1970, Piazza 1988, Pereira 2003). Accelerated ecosystem disturbance during the 18th century included rapid deforestation associated with Portuguese military fortification, agricultural expansion by Azorean colonists, and whaling. Throughout the 19th century and into the early 20th century, smallholders maintained economic activities in the coastal zone (Várzea 1985, Lago 1992, Zeferino et al. 1998) while new waves of European colonists, largely Italian and German, began to expand the agricultural frontier westward, gaining landholdings and establishing new manufacturing industries (Peluso 1991, Lago 2000 ). After 1950 , as the urban population grew and became concentrated, government planning agencies emerged and formulated master plans (Pereira 1978, Sugai 2002, Scherer et al. 2006). By the 1980s, continued economic restructuring toward an increasingly urban industrial society, evolving environmental policies, and increasing public concern over ecological issues helped to stabilize much of the forest cover that had already begun to regenerate after widespread agricultural abandonment in many of the longer-settled coastal areas (e.g., Caruso 1990, Marcelino et al. 2003).

\section{Data sources and limitations}

Demographic and agricultural censuses conducted by the Instituto Brasileiro de Geografia e Estatística (Brazilian Institute of Geography and Statistics) provide state and municipal-level data on changes in the human population and vegetation cover. Santa Catarina's municipal boundary base map is available as a vector file in CorelDRAW format at the state's government website (Santa Catarina 2002). I acquired aerial photographs for 1957 and 1998 from the library of the Instituto de Planejamento Urbano de Florianópolis (Florianópolis Urban Planning Institute).

Land-use tables in the agricultural censuses for the years 1970, 1975, 1980, 1985, and 1995-1996 report the extent of cropland, fallow, pasture, natural 
Fig. 3. Photograph of the metropolitan Florianópolis city center and its vicinity. The view is from the Desterro Environmental Conservation Unit (Unidade de Conservação Ambiental do Desterro), Santa Catarina Island. Photo: S. R. Baptista, 14 June 2004.

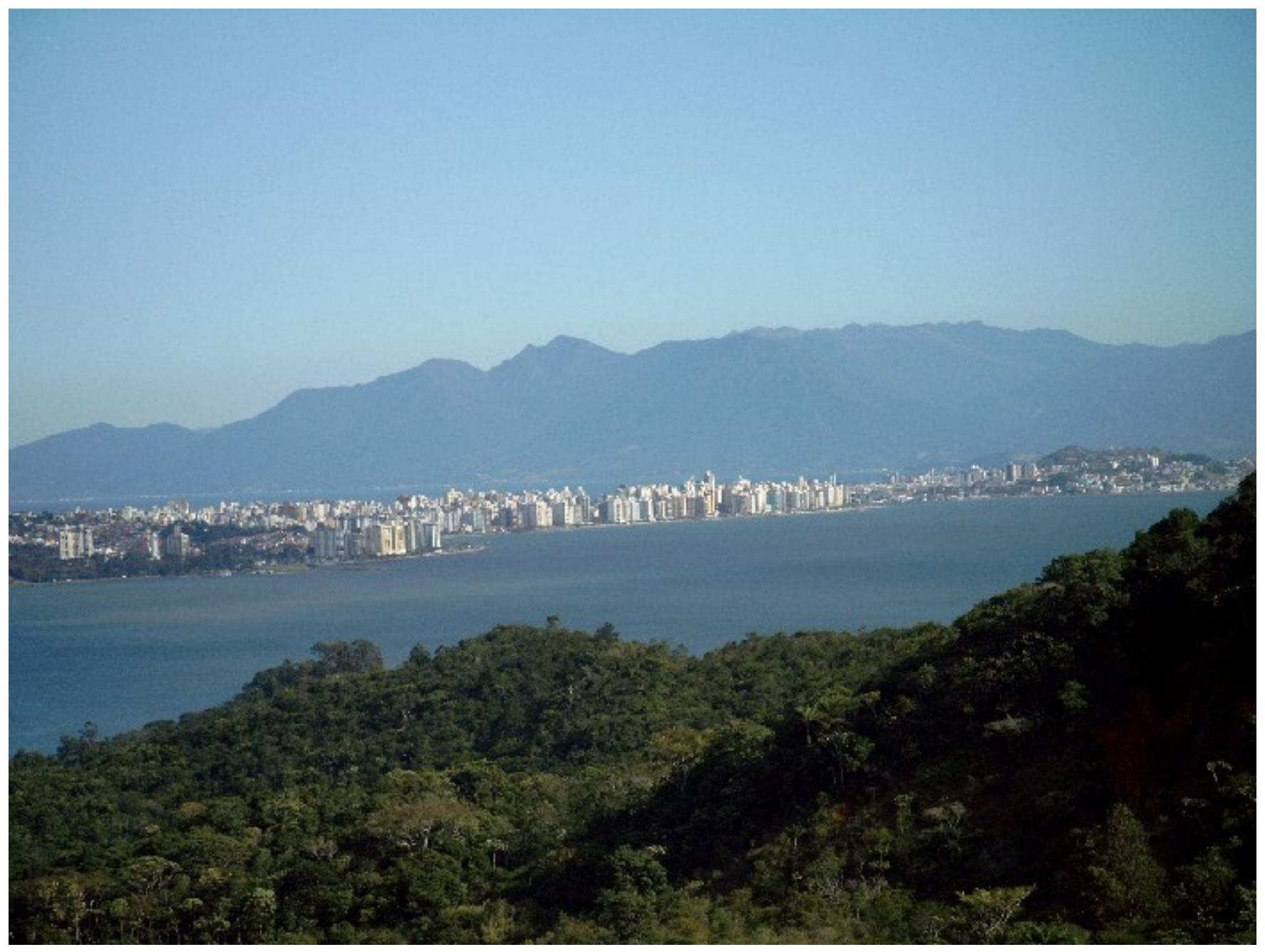

forest, and planted forest for each municipality. By analyzing land-use changes over this period, I expected to gain insight into landscape dynamics in the study region and to better understand the landuse history preceding the 2005 remote sensing assessment of forest cover by the Fundação SOS Mata Atlântica and Instituto Nacional de Pesquisas Espaciais (2006). Unlike satellite imagery, which offers the advantage of complete areal coverage, the agricultural censuses are limited to characteristics of rural private properties. However, changes over time in the ratio of rural private land to overall land area are important to consider in view of the consulted literature documenting urbanization and agricultural intensification in the region. Because of a difference in the seasonal timing of data collection, the potential lack of comparability between the 1995-1996 agricultural census data and data from the earlier agricultural censuses (see Instituto Brasileiro de Geografia e Estatística 1998, Helfand and Brunstein 2000) should be kept in mind, particularly for nonforest categories. However, this may be less of a concern for studies of southern Brazil, where the percentage of hired 
labor in the agricultural sector is much lower than in the country's center-west and southeast (Helfand and Brunstein 2000). Jepson (2005) has recently questioned the reliability of agricultural census data for the Cerrado, Brazil's tropical savanna. Jepson's (2005) case study took place in a frontier region of eastern Mato Grosso, where accessibility to remote areas may have interfered with data collection by agricultural census takers. In contrast, rural properties in eastern Santa Catarina have been more easily accessible given its longer history of postColumbian settlement and development.

\section{RESULTS}

\section{Demographic change}

Santa Catarina's population rose from nearly $1.2 \times$ $10^{6}$ people in 1940 to $>5.3 \times 10^{6}$ people in 2000 (Fig. 4). Its rural population gradually increased from $\sim 9.2 \times 10^{5}$ in 1940 to a peak of $\sim 1.7 \times 10^{6}$ in 1970 and then declined to $\sim 1.1 \times 10^{6}$ in 2000 . Its urban population grew from $2.5 \times 10^{5}$ to $\sim 1.1 \times$ $10^{6}$ people between 1940 and 1970 . As the rural population began to fall after 1970, the number of urban dwellers continued to grow, surpassing the rural population between 1970 and 1980. By 2000, Santa Catarina had $>4.2 \times 10^{6}$ urban inhabitants, representing nearly $80 \%$ of its total population.

Over four decades, the population of the Florianópolis metropolitan region (FMR) increased from $\sim 2.4 \times 10^{5}$ in 1960 to $\sim 8.2 \times 10^{5}$ people in 2000 (Fig. 4). The FMR's rural population peaked in approximately 1970 at $\sim 1.4 \times 10^{5}$ people. The number of urban dwellers surpassed the number of rural dwellers well before 1970. By 2000, the FMR urban population, which was $\sim 1.1 \times 10^{5}$ in 1960 , had increased to $\sim 7.4 \times 10^{5}$ while its rural population had declined to $\sim 8.0 \times 10^{4}$. The population declined in six FMR municipalities between 1991 and 2000: Alfredo Wagner, Major Gercino, Leoberto Leal, Angelina, Anitápolis, and São Bonifácio. All six are located inland at altitudes $>400 \mathrm{~m}$ above sea level and are among the FMR municipalities with the lowest population densities.

In 2000, Santa Catarina's average population density was 56 people $/ \mathrm{km}^{2}$ compared to 30 people/ $\mathrm{km}^{2}$ in 1970. Much of Santa Catarina's population growth from 1970 to 2000 was concentrated in the more urbanized eastern municipalities (Fig. 5). The average population density of the FMR was 47 people $/ \mathrm{km}^{2}$ in 1970 , with Florianópolis at 307 people $/ \mathrm{km}^{2}$ and the lowest municipal population density in Anitápolis and São Bonifácio at 8 people/ $\mathrm{km}^{2}$. By 2000, the population densities of Anitápolis and São Bonifácio had dropped to 6 and 7 people/ $\mathrm{km}^{2}$, respectively, whereas that of Florianópolis had increased to 780 people $/ \mathrm{km}^{2}$ and that of São José had reached 1522 people $/ \mathrm{km}^{2}$.

Florianópolis, São José, Palhoça, and Biguaçu, which compose the Florianópolis conurbation, currently receive more urban than rural migrants. However, over the past half-century there has been a significant influx of rural migrants attributed to the low income, instability, and difficulty of agricultural work; the lack of property ownership; and inadequate health care in rural areas (Casagrande 2006). The rural-urban migration rate increased from 1950 to 1985 , peaking during 1985 1990, and then declined from the 1990s onward (Casagrande 2006). After Santa Catarina's internal migrant flow, the next most common origins of migrants to the Florianópolis conurbation are the states of Rio Grande do Sul, Paraná, São Paulo, and Rio de Janeiro. In 2000, approximately $85.3 \%$ of the 816,419 FMR residents had been born in Santa Catarina, whereas $5.8 \%$ had been born in Rio Grande do Sul, 3.5\% in Paraná, 2.0\% in São Paulo, $1.0 \%$ in Rio de Janeiro, and $0.5 \%$ outside of Brazil (Instituto Brasileiro de Geografia e Estatística 2001). Of the 40,891 in-migrants $>5 \mathrm{yr}$ of age who originated from outside Santa Catarina between 1995 and 2000, 34.8\% were from Rio Grande do Sul, $21.1 \%$ from Paraná, $17.5 \%$ from São Paulo, $5.3 \%$ from outside of Brazil, and $5.1 \%$ from Rio de Janeiro (Instituto Brasileiro de Geografia e Estatística 2001).

\section{Rural land-use change}

In the early 1960s, maize led the list of major crops in Santa Catarina, covering $~ 3420 \mathrm{~km}^{2}$, followed by wheat $\left(\sim 1000 \mathrm{~km}^{2}\right)$, manioc $\left(\sim 950 \mathrm{~km}^{2}\right)$, and black beans $\left(\sim 870 \mathrm{~km}^{2}\right)$. In the littoral zone, manioc, rice, and sugarcane were dominant (Noble 1967). By the mid-1990s, tobacco had expanded from only $\sim 220$ $\mathrm{km}^{2}$ in 1962 to $5965 \mathrm{~km}^{2}$, claiming $19 \%$ of the state's cropland. Maize $(18 \%)$, beans $(7 \%)$, and rice $(5 \%)$ remained major crops, and soybean production expanded to $\sim 8 \%$ of the total cropland area (Instituto Brasileiro de Geografia e Estatística 1998). 
Fig. 4. Demographic trends in Santa Catarina and the Florianópolis metropolitan region. Source: Instituto Brasileiro de Geografia e Estatística (1964, 1974b, 1983b, 1996, 1997, 2001, 2007a,b).

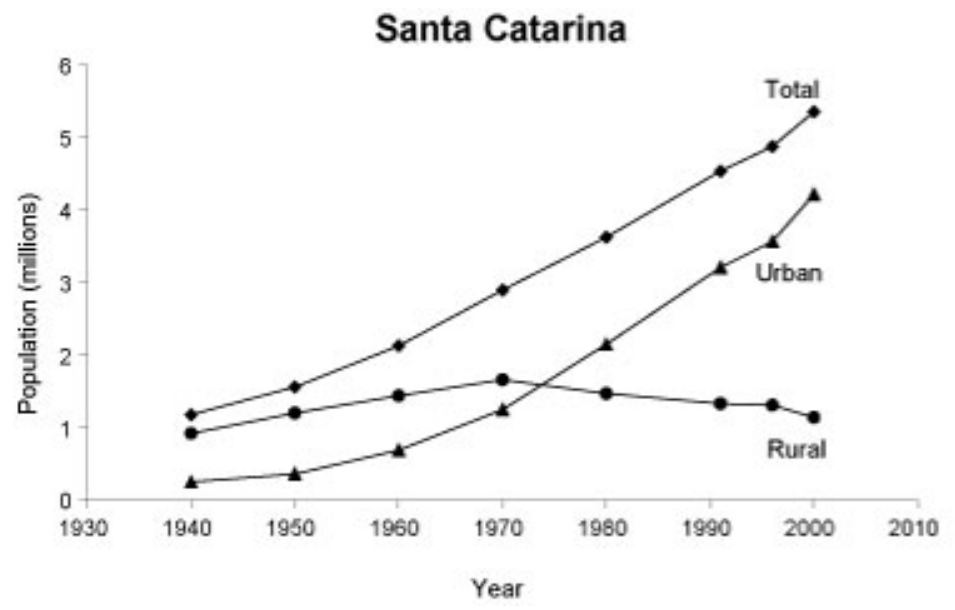

Florianópolis Metropolitan Region

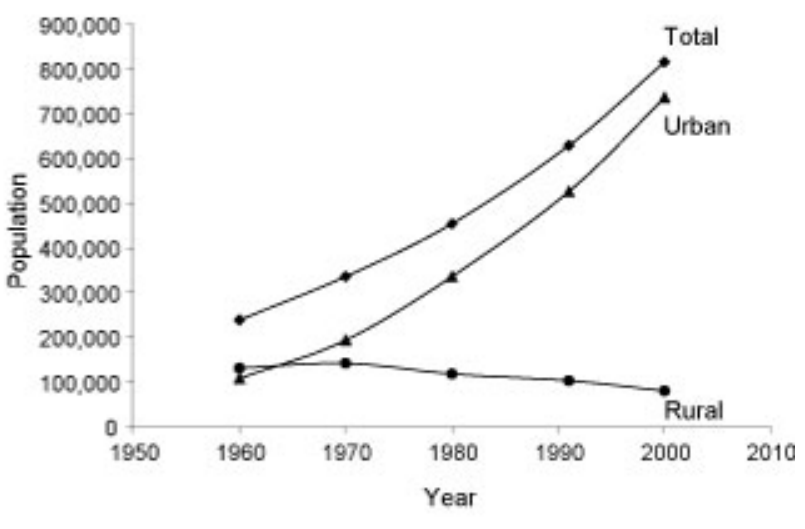

Agricultural census data for 1970 to 1995-1996 indicate that rural private property in Santa Catarina fluctuated between 69.2 and $78.3 \%$ of the state's total area (Fig. 6A). Cropland expanded from 1970 to 1985 , peaking at $18,688 \mathrm{~km}^{2}$, and then decreased to $15,704 \mathrm{~km}^{2}$ by $1995-96$. Pasture area reached a high of $24,909 \mathrm{~km}^{2}$ in 1980 and declined to a low of $23,389 \mathrm{~km}^{2}$ by $1995-1996$. Fallow declined from $11,100 \mathrm{~km}^{2}$ in 1970 to $2939 \mathrm{~km}^{2}$ in $1995-1996$. These three land cover types contracted at approximately the same rate between 1985 and the mid-1990s as the total number of agricultural establishments declined from 234,973 to 203,347. Cattle production was the most extensive rural activity in the mid-1990s $\left(16,378 \mathrm{~km}^{2}\right)$, when there was nearly $3.1 \times 10^{6}$ head of cattle compared to the $2.6 \times 10^{6}$ head reported in 1980 .

In the FMR, rural private lands declined after 1980. Cropland, fallow, and pasture all contracted from 1985 to $1995-1996$ (Fig. 6A). Cropland declined to $410 \mathrm{~km}^{2}$ and fallow decreased to $163 \mathrm{~km}^{2}$. Maize, harvested from $\sim 125 \mathrm{~km}^{2}(\sim 30 \%)$, along with tobacco $(\sim 9 \%)$, manioc $(\sim 8 \%)$, beans $(\sim 8 \%)$, and rice $(\sim \%)$ accounted for nearly $60 \%$ of $1995-1996$ cropland in the FMR. Pasture expanded rapidly in the FMR from 1975 to 1980; its increase slowed from 1980 to 1985 , reaching $1367 \mathrm{~km}^{2}$ in 1985 . In the following decade, pasture declined by $\sim 246 \mathrm{~km}^{2}$ to a level well below that of 1980 .

\section{Forest cover change}

Previous research on Santa Catarina showed that the overall net gain in private forest area after 1975 resulted from the expansion of planted forest with non-native species, even as natural forest continued to contract, and that initially, most of these planted forests emerged on lowlands, but began to become concentrated at higher altitudes after 1980 (Baptista and Rudel 2006). At the metropolitan scale, it appears that a forest transition began in the FMR at roughly the same time, but with some fluctuation (Fig. 6B). From 1980 to 1985 , the net increase in planted forest (563 ha) did not sufficiently offset the net loss of natural forest (3111 ha), resulting in an overall net forest loss. In contrast, from 1985 to 1995-1996 natural forest expansion (19,911 ha) far exceeded planted forest expansion (2825 ha), accounting for almost $88 \%$ of the total net forest increase of 22,736 ha (Table 1 ).

Twelve FMR municipalities experienced forest expansion on rural private property from 1985 to 1995-1996 (Fig. 7). Private forest gains occurred mostly in the more rural, inland, higher-altitude municipalities, whereas private forest losses occurred mainly in the coastal zone. Natural forest resurgence on private property occurred primarily in the municipalities of Alfredo Wagner (+6952 ha), Angelina (+6717 ha), São Bonifácio (+6171 ha), 
Fig. 5. Distribution of municipalities in Santa Catarina with > 30,000 inhabitants in 1970 and 2000. Source: Instituto Brasileiro de Geografia e Estatística (1974b, 2001).
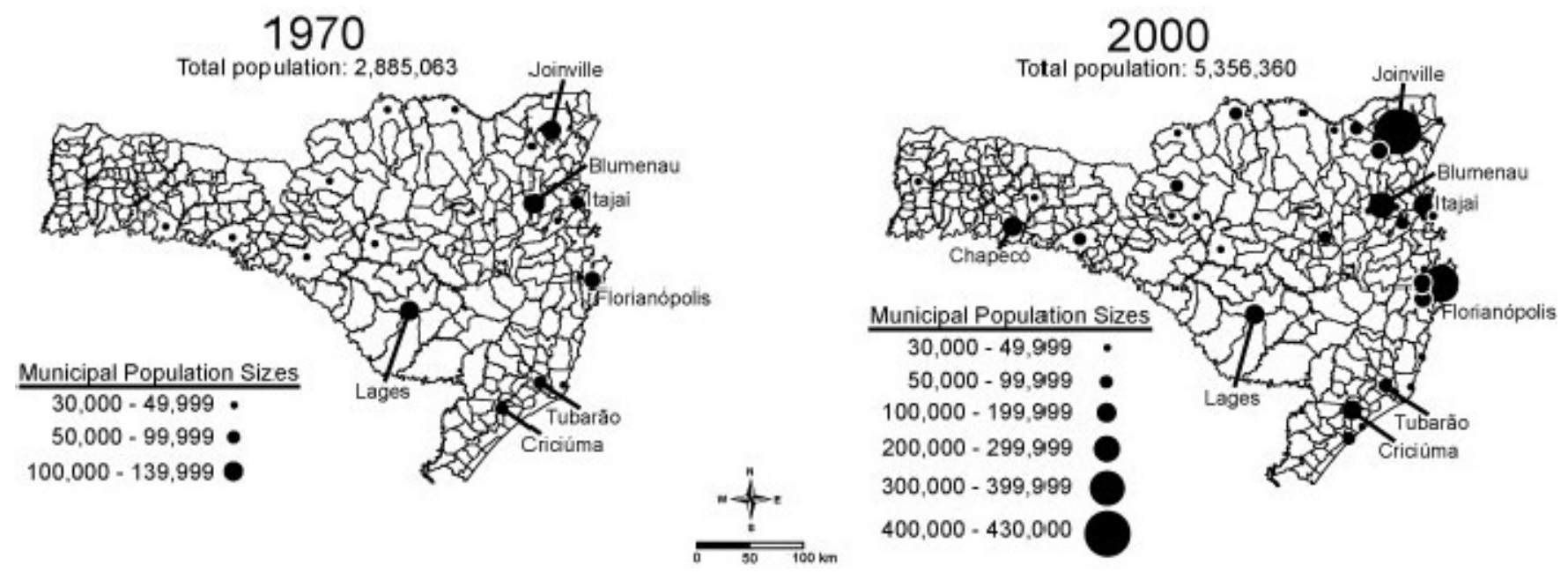

and Leoberto Leal (+4362 ha). The largest losses of natural forest cover on private lands from 1985 to 1995 occurred in Paulo Lopes (-8637 ha), Tijucas (-3140 ha), Palhoça (-1856 ha), and Biguaçu $(-1147$ ha). During the same period, substantial planted forest harvesting occurred in Palhoça (-2070 ha), Florianópolis (-546 ha), and Tijucas (-374 ha), and major planted forest gains occurred in Leoberto Leal (+1963 ha), Nova Trento $(+1109$ ha), Anitápolis (+1152 ha), Major Gercino (+952 ha), and São Bonifácio (+758 ha). By the mid-1990s, the FMR contained 124,989 ha of privately owned forest, of which $85.4 \%$ was natural and $14.6 \%$ was planted (Table 1). Natural forest covered $32.5 \%$ of the region's total private rural area, whereas planted forest covered 5.6\%. Despite an overall reduction in the extent of rural private property after 1980, private natural forests covered more of the FMR in the mid-1990s than in 1970. Although pasture area remained greater than private forest area in Santa Catarina over the entire period analyzed, the FMR contained substantially more private forest than pasture by the mid-1990s because of declining pasture area and forest regrowth after 1985 (Fig. 6C).

\section{DISCUSSION}

\section{Migration, urban segregation, and changes in pasture}

Santa Catarina and many other Brazilian states have experienced rural depopulation and accelerated urbanization since the 1970s (e.g., Peluso 1991, Hodge et al. 1997, Perz 2000, Scherer et al. 2006). In recent decades, people of both rural and urban origin have become concentrated in and near Florianópolis in the hope of accessing better jobs, housing, services, and amenities. Although some rural-urban migration toward life opportunities in urbanized coastal areas has continued, urban-urban migration originating from cities both inside and outside of Santa Catarina explains much more of the population increase in the Florianópolis metropolitan region (FMR) coastal municipalities during the late 20th century. Tourism has become a major source of jobs and revenue throughout contemporary Brazil (Santana 2000). Coastal tourism development in Santa Catarina began in the 1970s (Campos 2002, Reis 2002, Pereira 2003).

In response to the declining quality of life in the country's largest metropolises since the 1980s, many Brazilians have been migrating to new metropolises (Souza 2001; see also Telles 1995, 
Fig. 6. Land-use change on rural private property in Santa Catarina and the Florianópolis metropolitan region from 1970 to 1995-1996. Change in (A) total rural area, pasture, cropland, and fallow; (B) forest types; and (C) forest, pasture, cropland, and fallow. Source: Instituto Brasileiro de Geografia e Estatística $(1974 a, 1979,1983 a, 1990,1998)$.

(A)

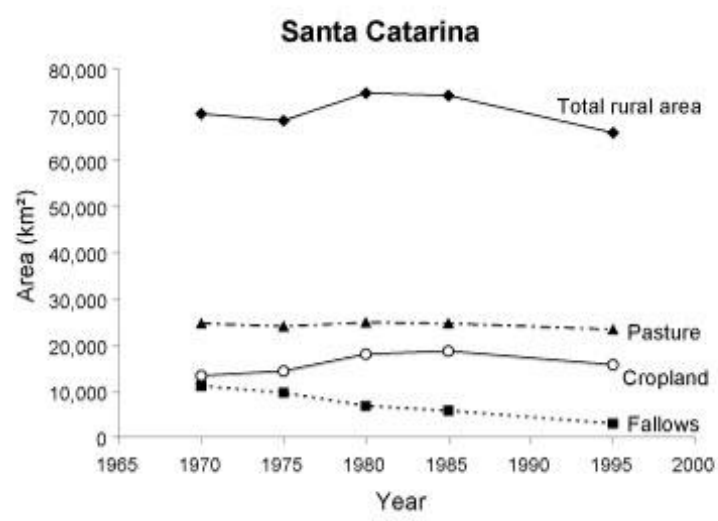

(B)

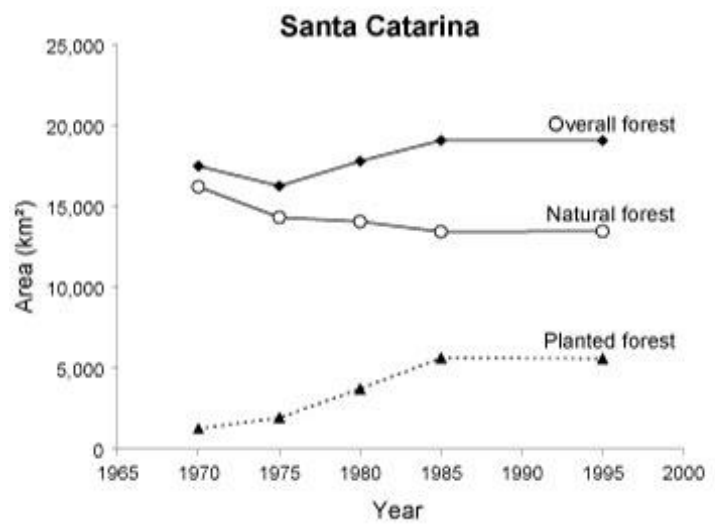

(C)

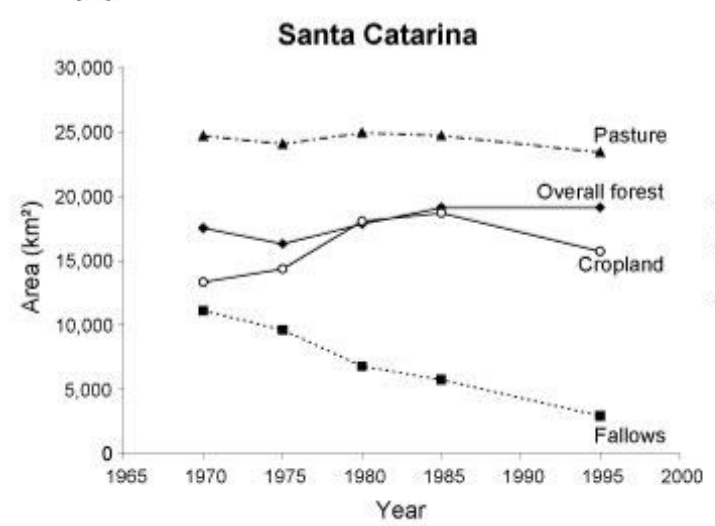

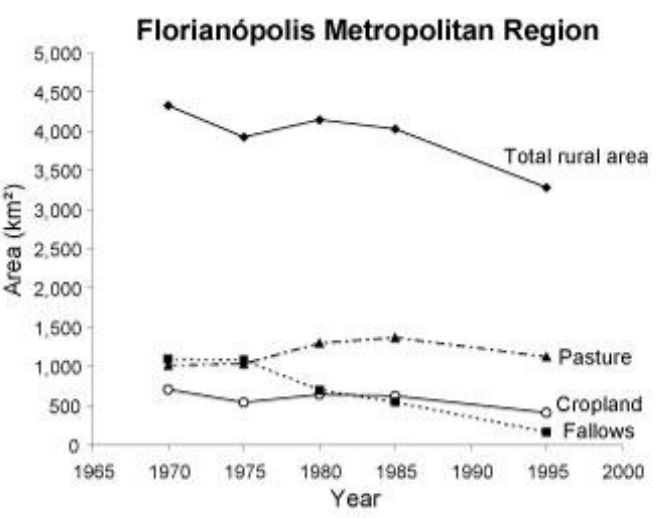

Florianópolis Metropolitan Region
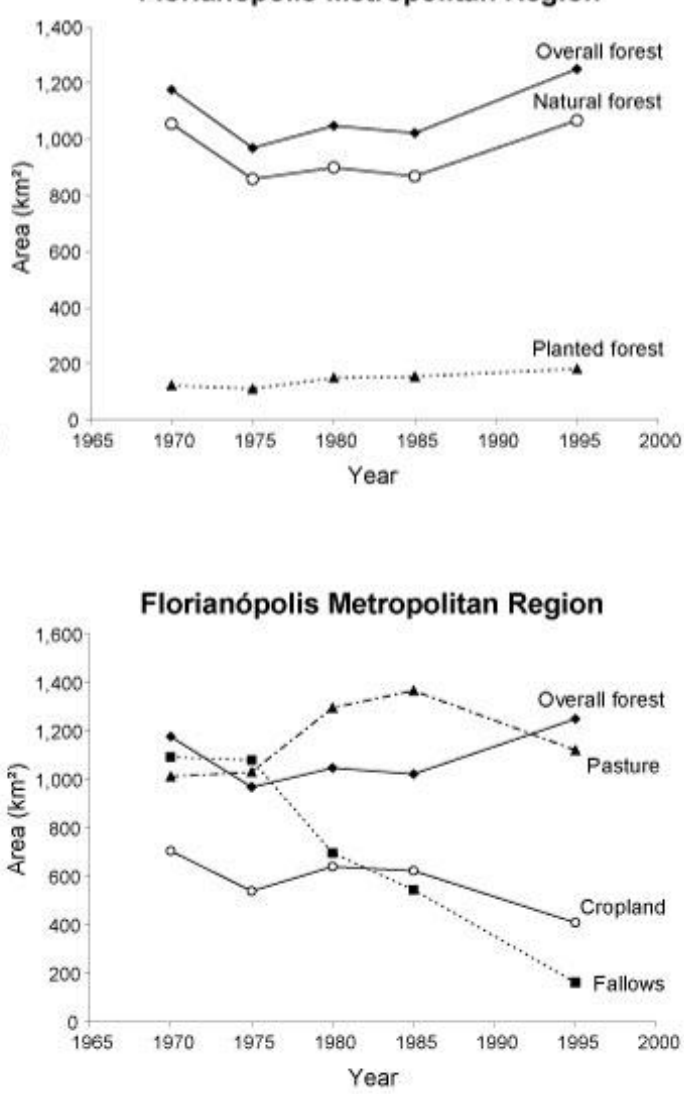
Table 1. Extent of rural private property and private forests in the Florianópolis metropolitan region (FMR), 1970 to $1995-1996$.

\begin{tabular}{|c|c|c|c|c|c|}
\hline \multirow{2}{*}{$\begin{array}{l}\text { Agricultural census } \\
\text { year }\end{array}$} & \multicolumn{2}{|c|}{ Extent of rural private property in the FMR } & \multicolumn{3}{|c|}{ Area of private forests in the FMR (ha) } \\
\hline & Area (ha) & $\begin{array}{c}\text { Proportion of FMR total area } \\
(\%)\end{array}$ & All forests & Natural forests & Planted forests \\
\hline 1970 & 432,680 & 61 & 117,726 & 105,520 & 12,206 \\
\hline 1975 & 392,658 & 55 & 96,928 & 85,793 & 11,135 \\
\hline 1980 & 414,756 & 58 & 104,801 & 89,947 & 14,854 \\
\hline 1985 & 403,008 & 57 & 102,253 & 86,836 & 15,417 \\
\hline 1995-1996 & 328,173 & 46 & 124,989 & 106,747 & 18,242 \\
\hline
\end{tabular}

Source: Instituto Brasileiro de Geografia e Estatística (1974a, 1979, 1983a, 1990, 1998).

Rolnik 2001). These migrants have moved to distance themselves from extreme levels of poverty and violence, high rates of unemployment and underemployment, high costs of living, and environmental problems. Souza (2001) has referred to this process as metropolitan deconcentration and extended suburbanization. Real estate developers and other entrepreneurs both attract and follow these flows of upper- and middle-income migrants. The recently accelerated growth of Florianópolis represents a dramatic example of this broader demographic trend as the city-region has experienced a boom in popularity among many Brazilian and some nonBrazilian tourists, migrants, and real estate developers. Lower-income populations also aspiring to improve their quality of life have been drawn to Florianópolis and other emerging metropolises; however, they are usually constrained by limited access to financial resources, housing, services, jobs, and political power, and by other exclusionary social dynamics. Greater Florianópolis has become more economically polarized and residentially segregated (Marcon et al. 1987, Fantin 2000), partially as a result of public investment patterns (Sugai 2002). Like other Latin American cities, its urban morphology has become more heterogeneous. Residentially, it is formed by traditional and new middle-class neighborhoods, planned low-income housing, informal low-income housing (favelas), luxury residential units in highrise buildings, and gated enclaves of single-family homes (condomínios fechados; Marcon et al. 1987, Lago 1992, Oliveira 1999, Reis 2002, Coy 2006).

Given this history, the 1975-1985 increase in pasture in the FMR followed by decline (Fig. 6C) raises some interesting questions for future study. To what extent was this change related to real estate speculation (Lago 1992, Oliveira 1999, Campos 2002) whereby lands were converted to pasture while landowners awaited increases in land prices before either selling properties to developers or themselves developing properties into residential, commercial, or industrial subdivisions? Was this period of pasture expansion related to a societal shift toward urban labor markets, reducing the availability of farm laborers and thus making activities with relatively low labor requirements such as cattle rearing more attractive to landowners? Did this temporary pasture expansion reflect an increase in local demand for bovine products as a result of urban growth that was later met by industrial cattle breeding?

\section{New institutional arrangements for restoring forests and managing ecosystem services}

In the study region, new institutional arrangements among public and private actors have emerged for the purpose of managing the ecosystem services necessary to support the rapidly growing urban 
Fig. 7. Gains and losses in private forest cover in the Florianópolis metropolitan region from 1985 to 1995-1996. Source: Instituto Brasileiro de Geografia e Estatística (1990, 1998).

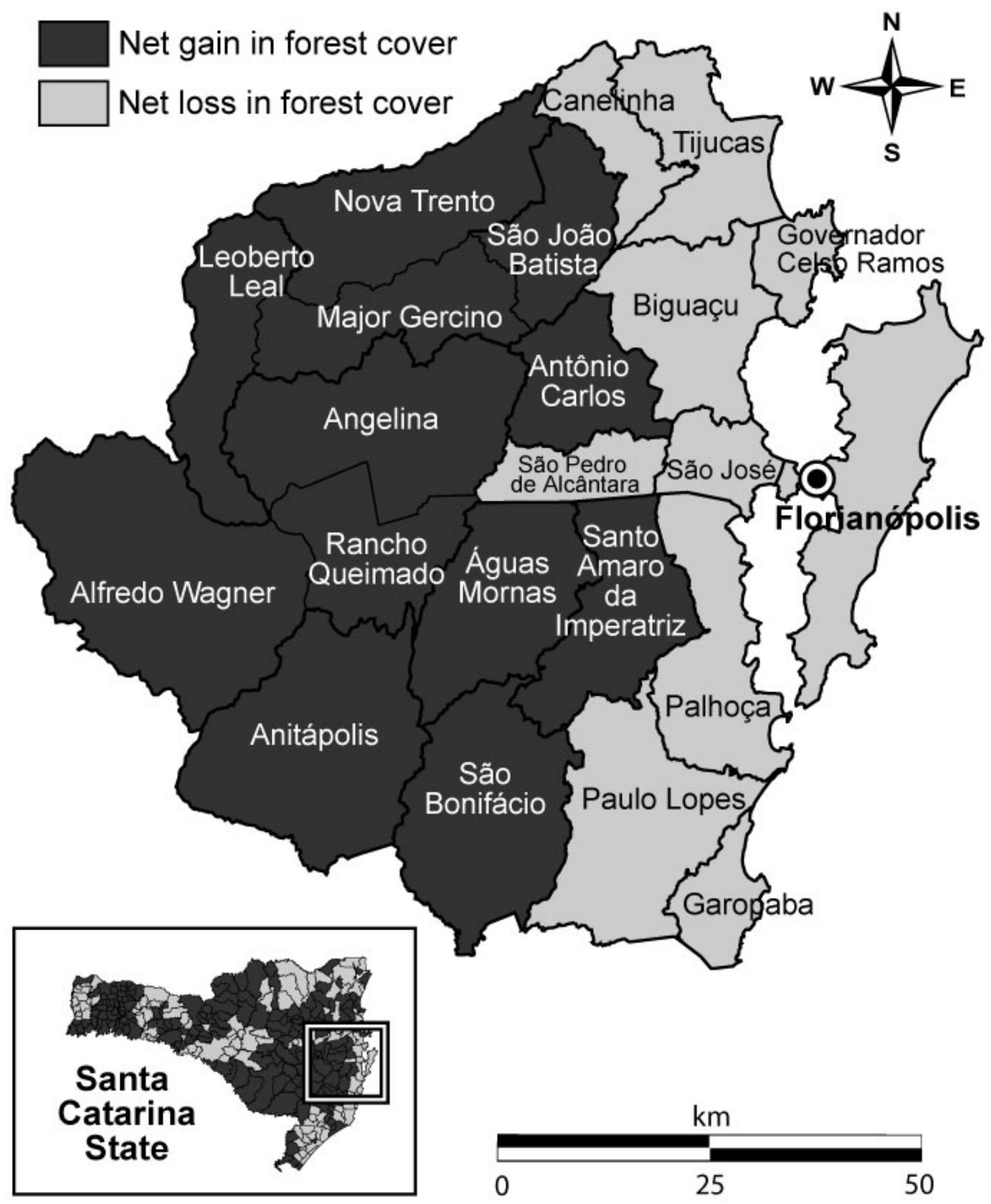


population, e.g., water provisioning, soil erosion control, and flood prevention, as well as the ecosystem functions that contribute to broader-scale ecological concerns such as biodiversity conservation and carbon sequestration. Rudel (2007) has referred to such institutional arrangements as conservation coalitions. Changes in institutional arrangements have been shown to influence forest recovery processes and outcomes (Southworth and Tucker 2001, Klooster 2003, Bray and Klepeis 2005, Ehlers 2007). One such important change in Brazil reflects a much broader trend in biodiversity conservation and ecosystem management toward planned integrated reserve-matrix systems (Bray and Klepeis 2005) to foster landscape-level habitat connectivity and natural resource sustainability (e. g., Galindo-Leal and Câmara 2003, Tabarelli et al. 2005, Brito 2006, Armesto et al. 2007). Others have documented the history of environmental governance in Brazil (e.g., Dean 1995, Brandon et al. 2005, Drummond and Barros-Platiau 2006) and Santa Catarina (Hodge et al. 1997, Scherer et al. 2006) and have described Santa Catarina Island's many protected areas (Centro de Estudos Cultura e Cidadania 1997, Hauff 1997, Queiroz et al. 2002). To illustrate the recent expansion of the FMR protected-area network, I provide two examples: a system of private nature reserves, the Reservas Particulares do Patrimônio Nacional (RPPNs); and Tabuleiro State Park (Parque Estadual da Serra do Tabuleiro).

RPPNs are privately owned protected areas that are recognized by Brazilian government authorities at either the federal or state level (Confederação Nacional de Reservas Particulares do Patrimônio Natural, http://www.rppnbrasil.org.br/). Introduced in 1990, the federal RPPN program is administered by the Brazilian Institute for the Environment and Renewable Natural Resources (Mittermeier et al. 2005). The potential of RPPNs for managing ecosystem services and biodiversity conservation is growing. By 2004, over 650 RPPNs existed in Brazil, protecting $\sim 6000 \mathrm{~km}^{2}$ (Castro and Borges 2004), of which 443 were within the Mata Atlântica, protecting $990 \mathrm{~km}^{2}$ (Costa et al. 2004, Mesquita 2004, Tabarelli et al. 2005). Of the Mata Atlântica RPPNs, 22 were in Santa Catarina, protecting nearly $145 \mathrm{~km}^{2}$. There are now approximately 10 RPPNs in the FMR, totaling roughly $47 \mathrm{~km}^{2}$ (Associação de Proprietários de Reservas Particulares do
Patrimônio Natural de Santa Catarina, http://www. rppncatarinense.org.br/).

Established by state decree in 1975 , Tabuleiro State Park protects $874 \mathrm{~km}^{2}$, including portions of Palhoça, Paulo Lopes, Santo Amaro da Imperatriz, São Bonifácio, Âguas Mornas, Garopaba, and Florianópolis. The comparison of aerial photographs of a 347-ha portion of Florianópolis and its adjacent communities taken in 1957 and 1998 shows substantial forest regeneration after four decades of agricultural abandonment and environmental protection (Fig. 8). Some traditional farmingfishing families were expelled by government environmental authorities; others were permitted to stay under a new set of land-use restrictions. The beach, Praia dos Naufragados, has evolved into a tourism and recreation site that is accessible by hiking through secondary forest or by boat. This is an example of forest recovery on public land in the FMR. Although beyond the scope of this article, systematic quantitative time-series analyses of existing aerial photographs of Florianópolis and satellite imagery of the entire FMR would add greater detail to this analysis. Other than the efforts already mentioned above, I am presently unaware of the existence of such studies.

\section{Uneven valuation of ecosystems and environmental amenities: threatened restingas}

For over three decades, the Florianópolis cityregion has been attracting migrants, university students, tourists, entrepreneurs, and investors. Its desirability stems from a combination of urban and natural resource amenities. Since 1970, public agencies, private developers, homeowners, and residents have become increasingly aware of the environmental amenities and ecosystem services associated with forests and other local ecosystems. One might hypothesize that this valuation of ecosystems and environmental amenities has provided some incentive to maintain and perhaps even restore vegetation cover associated with particular neighborhoods and properties. However, although forest recovery has occurred on many hillslopes, real estate development is converting adjacent areas to residential and commercial built environments. As Scherer et al. (2006) noted for 
Fig. 8. Forest recovery after agricultural abandonment and the creation of a protected area at the southern extreme of Santa Catarina Island. Source: Instituto de Planejamento Urbano de Florianópolis (Florianópolis Urban Planning Institute).

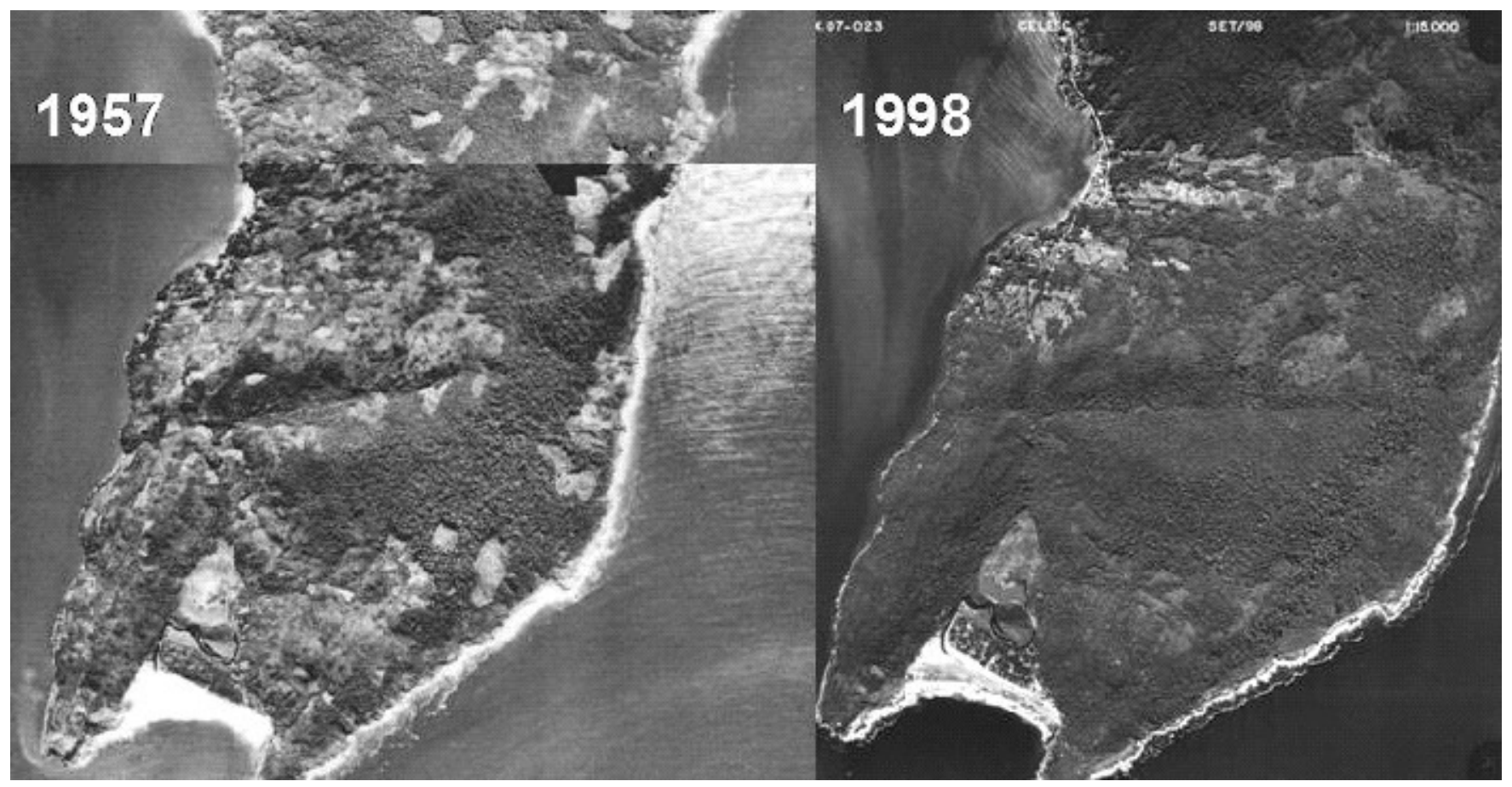

Laguna, and as I observed in Florianópolis during the 2000-2004 period, the accelerated urban expansion in Santa Catarina's coastal plain that has occurred without adequate planning and with lags in the provision of infrastructure and services is disturbing restinga ecosystems and thus affecting the dynamics of other coastal ecosystems, including forests. Further research should explore the relationship between the coastal real estate boom and organized efforts to mitigate anthropogenic environmental pressures by securing forest conservation and other forms of ecosystem protection. It is also important to ask how current urban expansion and ecosystem management trends are leading to uneven development (Smith 1984) and environmental injustice: Who has or does not have access to environmental amenities? How are environmental disamenities and their impacts distributed? How are ecosystem benefits distributed?

\section{Globalization}

There are many possible directions for inquiries linking globalization to forest recovery (e.g., Rudel 2002, Aide and Grau 2004, Hecht et al. 2006, Kull et al. 2007). Thus far, surprisingly little has been published relating forest transition dynamics to spatial configurations of socioeconomic inequality and poverty. Researchers can begin to remedy this gap by investigating landscapes that are undergoing metropolitanization and by examining processes of forest recovery or loss in the context of metropolitan spatial segregation. Diverse city-regions should be studied using research frameworks that elucidate the ways in which urban areas are interconnected, as well as how they are connected to nonurban landscapes. 


\section{CONCLUSION}

My results offer insight into current demographic, land-use, and institutional trends in southern and southeastern Brazil. More research is needed to better understand the relationship between metropolitan expansion and changes in forest cover in these regions, as well as the effects of emerging forests (Lugo and Helmer 2004) on biodiversity, habitats, and ecosystem functions. When used with other sources of information, particularly for longer-settled and more urbanized settings, demographic and agricultural censuses may provide useful data to inform research on forest recovery in Brazilian states, metropolitan regions, and municipalities. Evidence of metropolitanization with forest recovery in the Florianópolis metropolitan region (FMR) supports forest transition theory. Greater Florianópolis has undergone rapid demographic growth, accelerated real estate development, and economic polarization. The FMR has experienced the contraction of private agricultural land area, the expansion of protected area networks on public and private lands, and substantial forest recovery. Regenerating forests occur alongside urban, suburban, and peri-urban development. The complex social-ecological dynamics of this case should be compared to and integrated with knowledge of other city-regions.

Responses to this article can be read online at: http://www.ecologyandsociety.org/voll3/iss2/art5/responses/

\section{Acknowledgments:}

Field research during 2003-2004 was funded by a fellowship from the International Dissertation Field Research Fellowship Program of the Social Science Research Council with funds provided by the Andrew W. Mellon Foundation. Financial support for this paper was provided by the National Science Foundation (\#DEB-0731594). Special thanks to the many people in Florianópolis who shared their expertise and offered guidance, in particular, Maike Hering de Queiroz (in memoriam). I am also grateful to Thomas K. Rudel, Robin M. Leichenko, Laura C. Schneider, Diane C. Bates, and to the Graduate School of Rutgers University. Earlier versions of this manuscript benefited from the very helpful comments of the editors and several anonymous reviewers.

\section{LITERATURE CITED}

Aide, T. M., and H. R. Grau. 2004. Globalization, migration, and Latin American ecosystems. Science 305(5692):1915-1916.

Armesto, J. J., S. Bautista, E. Del Val, B. Ferguson, X. García, A. Gaxiola, H. GodinezÁlvarez, G. Gann, F. López-Barrera, R. Manson, M. Núñez-Ávila, C. Ortiz-Arrona, P. Tognetti, and G. Williams-Linera. 2007. Towards an ecological restoration network: reversing land degradation in Latin America. Frontiers in Ecology and the Environment 5(4):w1-w4.

Baptista, S. R., and T. K. Rudel. 2006. A reemerging Atlantic forest? Urbanization, industrialization and the forest transition in Santa Catarina, southern Brazil. Environmental Conservation 33(3):195-202.

Bonnet, A., M. H. de Queiroz, and O. J. Lavoranti. 2007. Relações de bromélias epifíticas com características dos forófitos em diferentes estádios sucessionais da Floresta Ombrófila Densa, Santa Catarina, Brasil. Floresta 37(1):83-94. Available online at: http://ojs.c3sl.ufpr.br/ojs2/index. php/floresta/article/view/7844/5536.

Brandon, K., G. A. B. da Fonseca, A. B. Rylands, and J. M. C. da Silva, editors. 2005. Special section: Brazilian conservation: challenges and opportunities. Conservation Biology 19(3):595-600.

Brannstrom, C. 2002. Rethinking the 'Atlantic Forest' of Brazil: new evidence for land cover and land value in western São Paulo, 1900-1930. Journal of Historical Geography 28(3):420-439.

Bray, D. B., and P. Klepeis. 2005. Deforestation, forest transitions, and institutions for sustainability in southeastern Mexico, 1900-2000. Environment and History 11(2):194-223.

Brito, F. A. 2006. Corredores ecológicos: uma estratégia integradora na gestão de ecossistemas. UFSC, Florianópolis, Brazil.

Brooks, T. M., R. A. Mittermeier, G. A. B. da Fonseca, J. Gerlach, M. Hoffmann, J. F. Lamoreux, C. G. Mittermeier, J. D. Pilgrim, and A. S. L. Rodrigues. 2006. Global biodiversity conservation priorities. Science 313(5783):58-61.

Cabral, O. R. 1970. História de Santa Catarina. Laudes, Rio de Janeiro, Brazil. 
Campos, N. J. de. 2002. Usos e formas de apropriação da terra na Ilha de Santa Catarina. Geosul 17(34):113-135.

Cardoso, F. H., and O. Ianni. 1960. Côr $e$ mobilidade social em Florianópolis: aspectos das relações entre negros e brancos numa comunidade do Brasil Meridional. Companhia Editora Nacional, São Paulo, Brazil.

Caruso, M. M. L. 1990. O desmatamento da Ilha de Santa Catarina de 1500 aos dias atuais. Second edition. UFSC, Florianópolis, Brazil.

Casagrande, W. A. 2006. Causas da migração rural-urbana na região da Grande Florianópolis: relatório de pesquisa-síntese regional. Epagri/ Cepa, Florianópolis, Brazil. Available online at: http://cepa.epagri.sc.gov.br/Publicacoes/causas\%20da\% 20migracao.pdf.

Castro, C. R., and M. E. Borges, editors. 2004. RPPN: conservação em terras privadas-desafios para a sustentabilidade. Confederação Nacional de Reservas Particulares do Patrimônio Natural, Planaltina do Paraná, Brazil.

Centro de Estudos Cultura e Cidadania. 1997. Unidades de Conservação e Áreas Protegidas da Ilha de Santa Catarina: caracterização $e$ legislação. Insular, Florianópolis, Brazil.

Cincotta, R. P., J. Wisnewski, and R. Engelman. 2000. Human population in the biodiversity hotspots. Nature 404(6781):990-992.

Clark, T. N., R. Lloyd, K. K. Wong, and P. Jain. 2002. Amenities drive urban growth. Journal of Urban Affairs 24(5):493-515.

Costa, C. M. R., M. M. Hirota, L. P. S. Pinto, M. T. da Fonseca, I. R. Lamas, M. C. W. de Brito, and C. A. B. Mesquita. 2004. Incentivo à criação e gestão de Reservas Particulares do Patrimônio Natural (RPPN): uma estratégia para a Conservação da Mata Atlântica. Pages 95-105 in C. R. Castro and M. E. Borges, editors. RPPN: conservação em terras privadas-desafios para a sustentabilidade. Confederação Nacional de Reservas Particulares do Patrimônio Natural, Planaltina do Paraná, Brazil.

Coy, M. 2006. Gated communities and urban fragmentation in Latin America: the Brazilian experience. GeoJournal 66(1-2):121-132.
Crane, P., and A. Kinzig. 2005. Nature in the metropolis. Science 308(5726): 1225.

Dean, W. 1995. With broadax and firebrand: the destruction of the Brazilian Atlantic forest. University of California Press, Berkeley, California, USA.

Drummond, J., and A. F. Barros-Platiau. 2006. Brazilian environmental laws and policies, 19342002: a critical overview. Law and Policy 28 (1):83-108.

Ehlers, E. 2007. Empreendedorismo e conservação ambiental no interior de São Paulo. Revista de Economia e Sociologia Rural 45(1):185-203. Available online at: http://www.scielo.br/pdf/resr/v 45n1/09.pdf.

Falkenberg, D. B. 1999. Aspectos da flora e da vegetação secundária da restinga de Santa Catarina, Sul do Brasil. Insula 28:1-30.

Fantin, M. 2000. Cidade dividida: dilemas e disputas simbólicas em Florianópolis. Cidade Futura, Florianópolis, Brazil.

Fundação SOS Mata Atlântica and Instituto Nacional de Pesquisas Espaciais. 1993. Evolução dos remanescentes florestais e ecossistemas associados do domínio da Mata Atlântica no período 1985-1990. Relatório. Fundação SOS Mata Atlântica, São Paulo, Brazil.

Fundação SOS Mata Atlântica and Instituto Nacional de Pesquisas Espaciais. 2002. Atlas dos remanescentes florestais da Mata Atlântica, período 1995-2000: relatório final. Fundação SOS Mata Atlântica, São Paulo, Brazil.

Fundação SOS Mata Atlântica and Instituto Nacional de Pesquisas Espaciais. 2006. Atlas dos remanescentes florestais da Mata Atlântica, período 2000-2005. Fundação SOS Mata Atlântica, Sâo Paulo, Brazil. Available online at: http://www. sosma.org.br.

Fundação SOS Mata Atlântica, Instituto Nacional de Pesquisas Espaciais, and Instituto Socioambiental. 1998. Atlas da evolução dos remanescentes florestais e ecossistemas associados no domínio da Mata Atlântica no período 19901995. Fundação SOS Mata Atlântica, São Paulo, Brazil. 
Galindo-Leal, C., and I. G. Câmara, editors. 2003. The Atlantic Forest of South America: biodiversity status, threats, and outlook. Island Press, Washington, D.C., USA.

Gospodini, A. 2006. Portraying, classifying and understanding the emerging landscapes in the postindustrial city. Cities 23(5):311-330.

Grainger, A. 1995. The forest transition: an alternative approach. Area 27(3):242-251.

Hauff, S. N. 1997. As áreas protegidas na Ilha de Santa Catarina. Pages 55-67 in Anais do I Congresso Brasileiro de Unidades de Conservação. Volume 2. Rede Nacional Pró-Unidades de Conservação and Fundação $O$ Boticário de Proteção à Natureza, Curitiba, Brazil.

Hecht, S. B., S. Kandel, I. Gomes, N. Cuellar, and H. Rosa. 2006. Globalization, forest resurgence, and environmental politics in El Salvador. World Development 34(2):308-323.

Helfand, S. M., and L. F. Brunstein. 2000. The changing structure of the Brazilian agricultural sector and the limitations of the 1995/96 Agricultural Census. Paper presented at the VII NEMESIS Seminar. Instituto de Pesquisa Economica Aplicada, Rio de Janeiro, Brazil.

Hodge, S. S., M. H. de Queiroz, and A. Reis. 1997. Brazil's national Atlantic Forest policy: a challenge for state-level environmental planning. The case of Santa Catarina, Brazil. Journal of Environmental Planning and Management 40(3):335-348.

Instituto Brasileiro de Geografia e Estatística. 1964. Censo demográfico 1960: Santa Catarina. Instituto Brasileiro de Geografia e Estatística, Rio de Janeiro, Brazil.

Instituto Brasileiro de Geografia e Estatística. 1974a. Censo agropecuário 1970: Santa Catarina. Instituto Brasileiro de Geografia e Estatística, Rio de Janeiro, Brazil.

Instituto Brasileiro de Geografia e Estatística. 1974b. Censo demográfico 1970: Santa Catarina. Instituto Brasileiro de Geografia e Estatística, Rio de Janeiro, Brazil.

Instituto Brasileiro de Geografia e Estatística.
1979. Censo agropecuário 1975: Santa Catarina. Instituto Brasileiro de Geografia e Estatística, Rio de Janeiro, Brazil.

Instituto Brasileiro de Geografia e Estatística. 1983a. Censo agropecuário 1980: Santa Catarina. Instituto Brasileiro de Geografia e Estatística, Rio de Janeiro, Brazil.

Instituto Brasileiro de Geografia e Estatística. 1983b. Censo demográfico 1980: Santa Catarina. Instituto Brasileiro de Geografia e Estatística, Rio de Janeiro, Brazil.

Instituto Brasileiro de Geografia e Estatística. 1990. Censo agropecuário 1985: Santa Catarina. Instituto Brasileiro de Geografia e Estatística, Rio de Janeiro, Brazil.

Instituto Brasileiro de Geografia e Estatística. 1996. Censo demográfico 1991: Santa Catarina. Instituto Brasileiro de Geografia e Estatística, Rio de Janeiro, Brazil.

Instituto Brasileiro de Geografia e Estatística. 1997. Contagem da população 1996. Instituto Brasileiro de Geografia e Estatística, Rio de Janeiro, Brazil.

Instituto Brasileiro de Geografia e Estatística. 1998. Censo agropecuário 1995/96: Santa Catarina. Instituto Brasileiro de Geografia e Estatística, Rio de Janeiro, Brazil. Available online at: http://www.ibge.gov.br/home/estatistica/economia/ agropecuaria/censoagro/1995 1996/default.shtm.

Instituto Brasileiro de Geografia e Estatística. 2001. Censo demográfico 2000: Santa Catarina. Instituto Brasileiro de Geografia e Estatística, Rio de Janeiro, Brazil. Available online at: http://www. ibge.gov.br/home/estatistica/populacao/ default censo 2000.shtm.

Instituto Brasileiro de Geografia e Estatística. 2004. Mapa de biomas do Brasil (primeira aproximação). Ministério do Meio Ambiente, Ministério do Planejamento, Orçamento e Gestão, Instituto Brasileiro de Geografia e Estatística, Diretoria de Geociências, Rio de Janeiro, Brazil. Available online at: http://www.ibge.gov.br/mapas ibge/geral tem.php.

Instituto Brasileiro de Geografia e Estatística. 2007a. Contagem da população. Instituto Brasileiro 
de Geografia e Estatística, Rio de Janeiro, Brazil. Available online at: http://www.ibge.gov.br/home/ estatistica/populacao/contagem2007/.

Instituto Brasileiro de Geografia e Estatística. 2007b. Tendências demográficas: uma análise da população com base nos resultados dos censos demográficos 1940 e 2000. Instituto Brasileiro de Geografia e Estatística, Rio de Janeiro, Brazil. Available online at: http://www.ibge.gov.br/home/ estatistica/populacao/tendencia demografica/ analise populacao/1940 2000/default.shtm.

Jepson, W. 2005. A disappearing biome? Reconsidering land-cover change in the Brazilian savanna. Geographical Journal 171(2):99-111.

Kauppi, P. E., J. H. Ausubel, J. Fang, A. S. Mather, R. A. Sedjo, and P. E. Waggoner. 2006. Returning forests analyzed with the forest identity. Proceedings of the National Academy of Sciences 103(46):17574-17579. Available online at: http://w ww.pnas.org/cgi/reprint/0608343103v1.

Klooster, D. 2003. Forest transitions in Mexico: institutions and forests in a globalized countryside. Professional Geographer 55(2):227-237.

Kull, C. A., C. K. Ibrahim, and T. C. Meredith. 2007. Tropical forest transitions and globalization: neo-liberalism, migration, tourism, and international conservation agendas. Society and Natural Resources 20(8):723-737.

Lago, M. C. S. 1992. Memória de uma comunidade que se transforma: um estudo de caso de processo de urbanização de uma comunidade de origem açoriana no litoral da Illha de Santa Catarina. Revista do Instituto Histórico e Geográfico de Santa Catarina 3(11):138-151.

Lago, P. F. 2000. Santa Catarina: a transformação dos espaços geográficos. Verde Água Produções Culturais, Florianópolis, Brazil.

Ley, D. 1980. Liberal ideology and the postindustrial city. Annals of the Association of American Geographers 70(2):238-258.

Lugo, A. E., and E. Helmer. 2004. Emerging forests on abandoned land: Puerto Rico's new forests. Forest Ecology and Management 190 (2-3):145-161.
Marcelino, E. V., L. A. da Conceição, and M. Adami. 2003. Análise evolutiva das formas de uso e cobertura do solo na microbacia Riacho do Poeta, Garopaba/SC: contribuição metodológica ao estudo ambiental. Geografia 28(2):225-240.

Marcon, M. T. de R., P. C. Pereira, P. P. Chiminello, R. J. Laureano, T. M. Fresca, and V. P. Veras. 1987. Patologia urbana: favelização no aglomerado urbano de Florianópolis. Geosul 4:53-64.

Mather, A. S. 1992. The forest transition. Area 24 (4):367-379.

Mather, A. S. 2005. Assessing the world's forests. Global Environmental Change 15(3):267-280.

Mather, A. S., and C. L. Needle. 1998. The forest transition: a theoretical basis. Area 30(2):117-124.

Mather, A. S., and C. L. Needle. 2000. The relationships of population and forest trends. Geographical Journal 166(1):2-13.

Mesquita, C.A. B. 2004. RPPN da Mata Atlântica: um olhar sobre as reservas particulares dos corredores de biodiversidade Central e Serra do Mar. Conservation International, Belo Horizonte, Brazil. Available online at: http://www.aliancamata atlantica.org.br/rppn final.pdf.

Metrodata. 2007. Informaçães básicas das regiões metropolitanas brasileiras. Observatório das Metrópoles, IPPUR/UFRJ-FASE, Rio de Janeiro, Brazil. Available online at: http://www.observatori odasmetropoles.ufrj.br/metrodata/ibrm/index.html

Millennium Ecosystem Assessment. 2005. Ecosystems and human well-being: synthesis. Island Press, Washington, D.C., USA. Available online at: http://www.millenniumassessment.org.

Mittermeier, R. A., G. A. B. da Fonseca, A. B. Rylands, and K. Brandon. 2005. A brief history of biodiversity conservation in Brazil. Conservation Biology 19(3):601-607.

Morellato, L. P. C., and C. F. B. Haddad. 2000. Introduction: the Brazilian Atlantic Forest. Biotropica 32(4b):786-792. 
Myers, N., R. A. Mittermeier, C. G. Mittermeier, G. A. B. da Fonseca, and J. Kent. 2000. Biodiversity hotspots for conservation priorities. Nature 403(6772):853-858.

Noble, A. G. 1967. Geographical aspects of the agriculture of Santa Catarina state, Brazil. Ohio Journal of Science 67(5):257-273. Available online at: https://kb.osu.edu/dspace/bitstream/1811/5325/1/ V67N05 257.pdf.

Oliveira, L. A. 1999. Formas de vir-a-ser cidade: loteamentos e condomínios na Ilha de Santa Catarina. Dissertation. University of São Paulo, São Paulo, Brazil.

Peluso, Jr., V.A. 1991. Estudos de geografia urbana de Santa Catarina. UFSC, Florianópolis, Brazil.

Pereira, N. V. 1978. Desenvolvimento $e$ modernização: um estudo de modernização em Florianópolis. Lunardelli, Florianópolis, Brazil.

Pereira, R. M. F.A. 2003. Formação sócio-espacial do litoral de Santa Catarina, Brasil: gênese e transformações recentes. Geosul 18(35):99-129.

Perz, S. G. 2000. The rural exodus in the context of economic crisis, globalization and reform in Brazil. International Migration Review 34 (3):842-881.

Perz, S. G. 2007. Grand theory and contextspecificity in the study of forest dynamics: forest transition theory and other directions. Professional Geographer 59(1):105-114.

Perz, S. G., and D. L. Skole. 2003. Secondary forest expansion in the Brazilian Amazon and the refinement of forest transition theory. Society and Natural Resources 16(4):277-294.

Piazza, W. F. 1988. A colonização de Santa Catarina. Lunardelli, Florianópolis, Brazil.

Queiroz, M. H., E. N. Mendonça, M. da Silva, S. Venturi, N. K. Vieira, R. Hiendlmayer, $M$. Mazzoli, E. N. Tiepo, U. Aner, A. Tomazi, E. Ferreira Filho, I. C. T. Andreatta, and I. Berkenbrock. 2002. Avaliação do grau de implementação das unidades de conservação da Ilha de Santa Catarina. Pages 405-414 in Anais do III Congresso Brasileiro de Unidades de Conservação.
Rede Nacional Pró-Unidades de Conservação, Fundação o Boticário de Proteção à Natureza, Associação Caatinga, Fortaleza, Brazil.

Reis, A. F. 2002. Permanências e transformações no espaço costeiro: formas e processo de crescimento urbano-turístico na Ilha de Santa Catarina. Dissertation. University of São Paulo, São Paulo, Brazil.

Rolnik, R. 2001. Territorial exclusion and violence: the case of the state of São Paulo, Brazil. Geoforum 32(4):471-482.

Rosenau, J. N. 1997. The complexities and contradictions of globalization. Current History 96 (613):360-364.

Rosenau, J. N. 2003. Distant proximities: dynamics beyond globalization. Princeton University Press, Princeton, New Jersey, USA.

Rudel, T. K. 1998. Is there a forest transition? Deforestation, reforestation, and development. Rural Sociology 63(4):533-552.

Rudel, T. K. 2002. Paths of destruction and regeneration: globalization and forests in the tropics. Rural Sociology 67(4):622-636.

Rudel, T. K. 2007. Changing agents of deforestation: from state-initiated to enterprise driven processes, 1970-2000. Land Use Policy 24 (1):35-41.

Rudel, T. K., O. T. Coomes, E. Moran, F. Achard, A. Angelsen, J. Xu, and E. Lambin. 2005. Forest transitions: towards a global understanding of the land use change. Global Environmental Change $\mathbf{1 5}$ (1):23-31.

Santa Catarina. 2000. Anuário estatístico do Estado de Santa Catarina. Secretaria de Estado do Desenvolvimento Econômico e Integração ao Mercosul, Florianópolis, Brazil.

Santa Catarina. 2002. Mapa político de Santa Catarina (1997). Governo do Estado Santa Catarina, Florianópolis, Brazil. Available online at: http://www.sc.gov.br/conteudo/santacatarina/geografia/ paginas/mapas.htm.

Santa Catarina. 2003. Caracterização regional: São José. Secretaria de Estado do Planejamento, 
Orçamento, e Gestão, Florianópolis, Brazil. Available online at: http://cepa.epagri.sc.gov.br/Pu blicacoes/diagnostico/SAO JOSE.pdf.

Santana, G. 2000. An overview of contemporary tourism development in Brazil. International Journal of Contemporary Hospitality Management 12(7):424-430.

Scherer, M., C. Ferreira, J. Mudat, and S. Cataneo. 2006. Urbanização e gestão do litoral centro-sul do estado de Santa Catarina. Desenvolvimento e Meio Ambiente 13:31-50. Available online at: http://ojs.c3sl.ufpr.br/ojs2/index. $\mathrm{php} / \mathrm{made} /$ article/view/4873.

Scott,A. J. 2001a. Globalization and the rise of cityregions. European Planning Studies 9(7):813-826.

Scott, A. J., editor. 2001b. Global city-regions: trends, theory, policy. Oxford University Press, Cambridge, UK.

Scudeller, V.V., F. R. Martins, and G. J. Shepherd. 2001. Distribution and abundance of arboreal species in the Atlantic ombrophilous dense forest in southeastern Brazil. Plant Ecology 152(2):185-199.

Smith, N. 1984. Uneven development: nature, capital, and the production of space. Blackwell, New York, New York, USA.

Southworth, J., and C. Tucker. 2001. The influence of accessibility, local institutions and socioeconomic factors on forest cover change in the mountains of western Honduras. Mountain Research and Development 21(3):276-283.

Souza, M. L. de. 2001. Metropolitan deconcentration, socio-political fragmentation and extended suburbanisation: Brazilian urbanisation in the 1980s and 1990s. Geoforum 32(4):437-447.

Sugai, M. I. 2002. Segregação silenciosa: investimentos públicos e distribuição sócioespacial na área conurbada de Florianópolis. Dissertation. University of São Paulo, São Paulo, Brazil.

Tabarelli, M., L. P. Pinto, J. M. C. Silva, M. Hirota, and L. Bedê. 2005. Challenges and opportunities for biodiversity conservation in the Brazilian Atlantic Forest. Conservation Biology 19 (3):695-700.
Telles, E. E. 1995. Structural sources of socioeconomic segregation in Brazilian metropolitan areas. American Journal of Sociology 100 (5):1199-1223.

Turner, II, B. L., W. C. Clark, R. W. Kates, J. F. Richards, J. T. Mathews, and W. B. Meyer, editors. 1990. The Earth as transformed by human action: global and regional changes in the biosphere over the past 300 years. Cambridge University Press with Clark University, Cambridge, UK.

United Nations Human Settlements Programme. 2003. The challenge of slums: global report on human settlements 2003. Earthscan, London, UK.

Várzea, V. 1985. Santa Catarina: a Ilha. Reprint of original 1900 edition. Lunardelli, Florianópolis, Brazil.

Vibrans, A. C. 2003. A recuperação da cobertura florestal numa subbacia do Rio Itajaí em Santa Catarina entre 1956 e 2000. Pages 611-618 in Anais XI Simpósio Brasileiro de Sensoriamento Remoto (Belo Horizonte, 2003). Instituto Nacional de Pesquisas Espaciais, São José, Brazil. Available online at: http://marte.dpi.inpe.br/col/ltid.inpe.br/ sbsr/2002/11.13.14.05/doc/05_132.pdf.

Vibrans, A. C., J. Pellerin, and J. C. Refosco. 2005. A cobertura florestal da bacia do Rio Itajaí em Santa Catarina. Pages 1691-1698 in Anais XII Simpósio Brasileiro de Sensoriamento Remoto. (Goiânia, 2005). Instituto Nacional de Pesquisas Espaciais, São José, Brazil. Available online at: htt p://marte.dpi.inpe.br/col/ltid.inpe.br/sbsr/2004/10.2 1.15.05/doc/1691.pdf.

Webb, T. J., F. I. Woodward, L. Hannah, and K. J. Gaston. 2005. Forest cover-rainfall relationships in a biodiversity hotspot: the Atlantic forest of Brazil. Ecological Applications 15(6):1968-1983.

Wright, S. J., and H. C. Muller-Landau. 2006. The future of tropical forest species. Biotropica 38 (3):287-301.

Zeferino, A. C., A. L. Santos, and M. R. Câmara. 1998. Velhos caminhos novos resgate histórico e geográfico dos caminhos da Ilha de Santa Catarina: suporte teórico e alguns relatos. Revista do Instituto Histórico e Geográfico de Santa Catarina 3 (17):101-150. 


\section{Zurita, G. A., N. Rey, D. M. Varela, M. Villagra,} and M. I. Bellocq. 2006. Conservation of the Atlantic Forest into native and exotic tree plantations: effects on bird communities from the local and regional perspectives. Forest Ecology and Management 235(1-3):164-173. 